\title{
Heme Oxygenase-1 Inhibition Sensitizes Human Prostate Cancer Cells towards Glucose Deprivation and Metformin-Mediated Cell Death
}

\author{
Marco Raffaele ${ }^{1}$, Valeria Pittalà ${ }^{2}{ }^{(0)}$, Veronica Zingales ${ }^{1}$, Ignazio Barbagallo ${ }^{1}{ }^{\circledR}$, \\ Loredana Salerno $^{2}{ }^{(0}$, Giovanni Li Volti ${ }^{3}{ }^{\circ}$, Giuseppe Romeo ${ }^{2} \oplus$, Giuseppe Carota ${ }^{1}$, \\ Valeria Sorrenti ${ }^{1}$ (D) and Luca Vanella $1, * \mathbb{C}$ \\ 1 Department of Drug Science, Biochemistry Section, University of Catania, 95125 Catania, Italy; \\ marco.raffaele@hotmail.com (M.R.); veronica_zingales@libero.it (V.Z.); ignazio.barbagallo@unict.it (I.B.); \\ giuseppe-carota@outlook.it (G.C.); sorrenti@unict.it (V.S.) \\ 2 Department of Drug Science, Pharmaceutical Chemistry Section, University of Catania, 95125 Catania, Italy; \\ vpittala@unict.it (V.P.); l.salerno@unict.it (L.S.); gromeo@unict.it (G.R.) \\ 3 Department of Biomedical and Biotechnological Sciences, University of Catania, 95125 Catania, Italy; \\ livolti@unict.it \\ * Correspondence: lvanella@unict.it; Tel.: +39-095-738-4077
}

Received: 18 April 2019; Accepted: 23 May 2019; Published: 27 May 2019

\begin{abstract}
High levels of heme oxygenase (HO)-1 have been frequently reported in different human cancers, playing a major role in drug resistance and regulation of cancer cell redox homeostasis. Metformin (MET), a drug widely used for type 2 diabetes, has recently gained interest for treating several cancers. Recent studies indicated that the anti-proliferative effects of metformin in cancer cells are highly dependent on glucose concentration. The present work was directed to determine whether use of a specific inhibitor of HO-1 activity, alone or in combination with metformin, affected metastatic prostate cancer cell viability under different concentrations of glucose. MTT assay and the xCELLigence system were used to evaluate cell viability and cell proliferation in DU145 human prostate cancer cells. Cell apoptosis and reactive oxygen species were analyzed by flow cytometry. The activity of HO-1 was inhibited using a selective imidazole-based inhibitor; genes associated with antioxidant systems and cell death were evaluated by qRT-PCR. Our study demonstrates that metformin suppressed prostate cancer growth in vitro and increased oxidative stress. Disrupting the antioxidant HO-1 activity, especially under low glucose concentration, could be an attractive approach to potentiate metformin antineoplastic effects and could provide a biochemical basis for developing HO-1-targeting drugs against solid tumors.
\end{abstract}

Keywords: prostate cancer; heme oxygenase; metformin; apoptosis; ER stress; HO-1 activity inhibitor

\section{Introduction}

Heme oxygenase-1 (HO-1) is the inducible isoform of heme oxygenase, the first rate-limiting enzyme in the degradation of heme to free iron, carbon monoxide (CO), and biliverdin [1].

HO-1 is present at low levels in many tissues and is highly upregulated by numerous stimuli, such as heme, heavy metals, UV irradiation, reactive oxygen species (ROS), polyphenols, and inflammatory cytokines [2,3]. HO-1 is mainly localized in microsomes, but it has also been demonstrated to be differently localized in caveolae, mitochondria, and nuclei [4-6].

Endogenous induction of HO-1 is widely acknowledged as an adaptive cellular response, able to counteract oxidative stress. Moreover, HO-1-derived metabolites have several protective effects on cells 
and tissues against injuries related to pathological conditions like diabetes, obesity, and cardiovascular diseases [7-13].

High levels of HO-1 have been frequently reported in different human cancers [14-16], playing a major role in drug resistance and regulation of cancer cell redox homeostasis [17-22].

Elevated HO-1 levels have been shown in many cancers, as reported by Jozkowicz et al. [23]. A previous study by Florczyk et al. [24] revealed that enhanced activity of biliverdin reductase may protect cells in stressful conditions arising from anti-cancer drugs, cisplatin, and doxorubicin. Additionally, data from Banerjee et al. [25] demonstrate that HO-1 is up-regulated in renal cancer cells as a survival strategy against chemotherapeutic drugs and promotes growth of tumor cells by inhibiting both apoptosis and autophagy. Thus, application of chemotherapeutic drugs along with HO-1 inhibitor may elevate therapeutic efficiency by reducing the cytoprotective effects of $\mathrm{HO}-1$ and by simultaneous induction of both apoptosis and autophagy.

Metformin (MET), a drug widely used for type 2 diabetes, has recently gained interest for treating several cancers [26]. The anti-proliferative effects of metformin, reported in several cancers including breast, colon, glioma, ovarian, pancreatic, and prostate cancer [27-29], have been mainly associated with the capacity of MET to inhibit mitochondrial respiration and consequently increasing glycolysis rates [30] and to arrest cell cycle and inducing caspase-dependent apoptosis [31,32].

An inverse relationship has been found between the progress of prostate cancer and type 2 diabetes in patients who use metformin.

Additionally, MET use had a trend of improving survival for prostate cancer patients $[33,34]$. Metformin was reported to reduce prostate cancer growth prominently under a high fat diet, acting through the modulation of several tumoral-associated processes in a xenograft model of human cell lines, using immunodeficient mice [35].

MET treatment and caloric restriction increase the AMP/ATP ratio and activate AMP-activated protein kinase (AMPK), switching cells from an anabolic to a catabolic state. Treatment of breast cancer cells with MET significantly decreased cholesterol content with concomitant inhibition of various cholesterol regulatory genes [36], suggesting that drugs affecting cholesterol synthesis, such as simvastatin/atorvastatin, could be used in the treatment of cancer [37].

Recent studies showed, in vitro, that MET, in combination with simvastatin, induced G1-phase cell cycle arrest [38], while, in vivo, treatment of mice with a combination of metformin and atorvastatin caused stronger inhibition than either drug used individually on the growth of PC-3 tumors [39]. Furthermore, it has been reported that combination treatment of MET with valproic acid was more effective at slowing prostate tumor growth in vivo compared to either drug alone, in mouse xenografts [40].

MET has been proposed to operate as an agonist of Sirtuin-1, a nicotinamide adenine dinucleotide (NAD+)-dependent deacetylase that mimics most of the metabolic responses to calorie restriction [41].

Most primary and metastatic human cancers show significantly increased glucose uptake because of their enhanced glucose consumption. Cancer cells are more dependent on glucose for energy production than normal cells [42,43]. Recent studies have indicated that the anti-proliferative effects of metformin in cancer cells are highly dependent on the glucose concentration [44,45].

Furthermore, it has been shown that metformin significantly decreases the intracellular glutathione levels and enhanced sensitivity of esophageal squamous cell carcinoma to cisplatin [46], suggesting that regulation of the antioxidant defenses represents a key target for cancer therapy. In this regard, new evidence has shown the involvement of TIGAR (TP53-induced glycolysis and apoptosis regulator) in glutathione restoration [47].

A growing body of independent evidence supports the association between metabolic alterations and the development and progression of prostate cancer, as well as the promising role of MET in controlling prostate cancer outcomes. 
The present work was directed to determine whether use of a specific inhibitor of HO-1 activity, alone or in combination with MET, would affect metastatic prostate cancer cell viability under different concentrations of glucose.

\section{Results}

\subsection{Effect of Metformin on Cell Viability}

It has been shown that MET is selectively toxic to p53-deficient cells and provides a potential mechanism for the reduced incidence of tumors observed in patients being treated with metformin [48]. Results obtained by Gonnissen et al. showed that p53-mutant cells were more resistant to MET than PC3 and 22Rv1 [49].

In order to determine whether MET affects proliferation of human p53-mutant prostate cancer cells, we analyzed the effect of the drug on DU145, a p53-mutant cell line [50]. DU145 was treated with different concentrations of MET (3-50 mM) for $24 \mathrm{~h}$, then the cell viability was assessed by MTT assay (Figure 1). In the presence of the highest concentration of MET $(50 \mathrm{mM})$, the cell viability was reduced by about $50 \%$ compared to treatment with the other concentrations, and about $80 \%$ compared to untreated cells. Consistent with previous studies, cell treatment with metformin showed significant cytotoxicity. The concentration of $10 \mathrm{mM}$ was used in the following experiments.

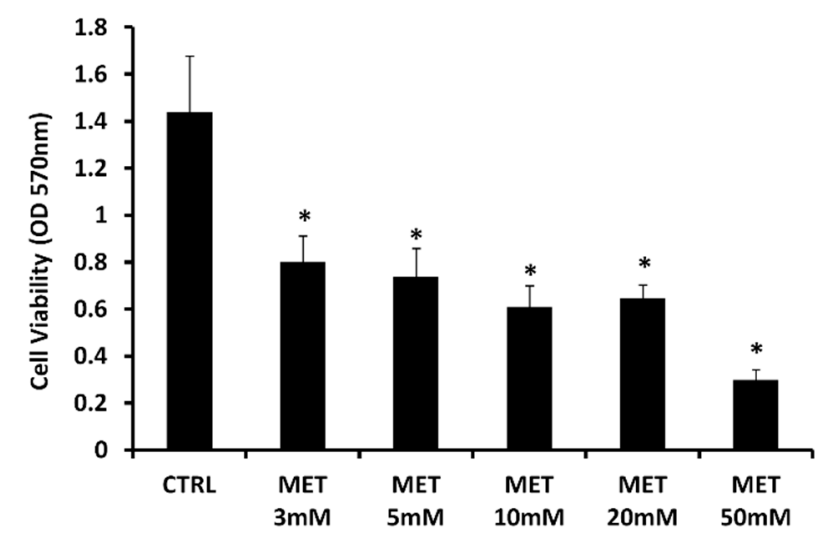

Figure 1. Metformin (MET) caused a decrease in cell viability. Cell viability, determined using MTT assay, of androgen-independent human prostate cancer cells (DU145), control untreated (CTRL) and treated with Metformin at different concentrations $(3,5,10,20$, and $50 \mathrm{mM})$ for $24 \mathrm{~h}$. Data are the means \pm SD of three experiments performed in triplicate ${ }^{*} p<0.05$ versus DU145 untreated cells.

\subsection{Real-Time Analysis of Cell Proliferation in Presence of Metformin and Different Glucose Concentrations}

In order to study the effect of MET on DU145 cells proliferation in conditions of glucose deprivation, dynamic changes in cell index were monitored using the xCELLigence system upon exposure to $1 \mathrm{mM}$ glucose (G1 control (CTRL)) or $25 \mathrm{mM}$ glucose (G25 CTRL) for $48 \mathrm{~h}$. The DU145 cells were untreated and treated with $10 \mathrm{mM}$ MET. The cell index of both control groups of untreated cells followed the same trend across the $48 \mathrm{~h}$. After $24 \mathrm{~h}$, the cell index of cell groups treated with MET followed different trends, showing a noticeable gap at the end of $48 \mathrm{~h}$.

As shown in Figure 2, low glucose concentration enhanced MET cytotoxicity in DU145 cells at $24 \mathrm{~h}$ and $48 \mathrm{~h}$. 


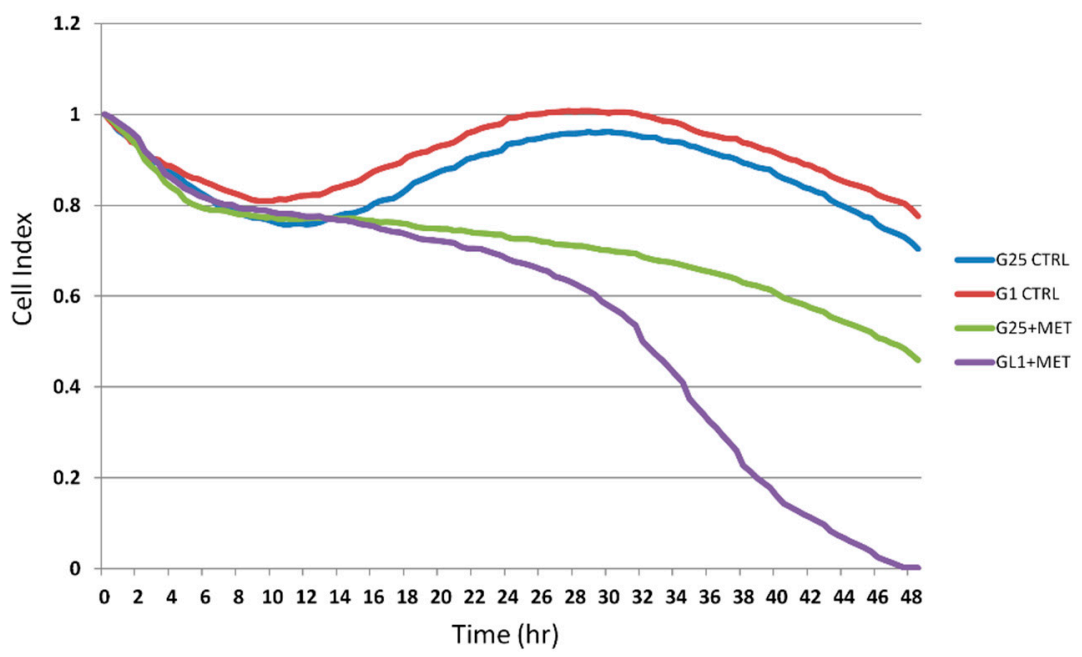

Figure 2. Metformin decrease cell proliferation in presence of different glucose concentrations. DU145 proliferation in the different groups recorded in real time, using the xCELLigence system. The cells showed growth with $1 \mathrm{mM}$ glucose (G1) or $25 \mathrm{mM}$ glucose (G25) in presence and absence of $10 \mathrm{mM}$ metformin (MET).

\subsection{Effect of Metformin on HO-1, CHOP, BAX, and Sirtuins mRNA Expression}

The effect of MET on HO-1, CHOP and BAX, genes related to the endoplasmic reticulum stress and apoptosis activation, was assessed by measuring mRNA levels. Their gene expression followed the same trend, with an increased level after MET administration, compared to the control group (Figure 3A-C). In order to analyze the effect of metformin on the pathway related to apoptosis regulation, mRNA levels of different sirtuins were assessed. Treatment with $10 \mathrm{mM}$ MET led to an increase of Sirt1 levels, more pronounced in the highest concentration of glucose. Conversely, Sirt3 and Sirt5 levels were reduced after treatment, in both concentrations of glucose. The low concentration of glucose caused a significant decrease of Sirt3 and Sirt5 levels, even in the absence of MET (Figure 3D-F).

A

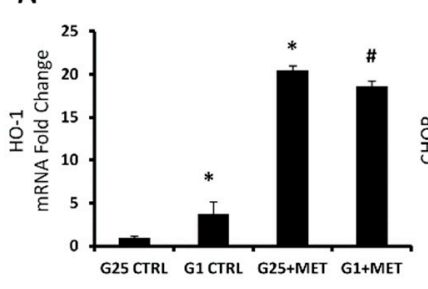

D

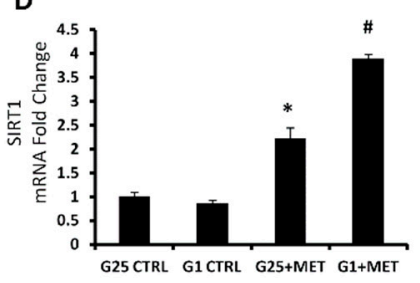

B
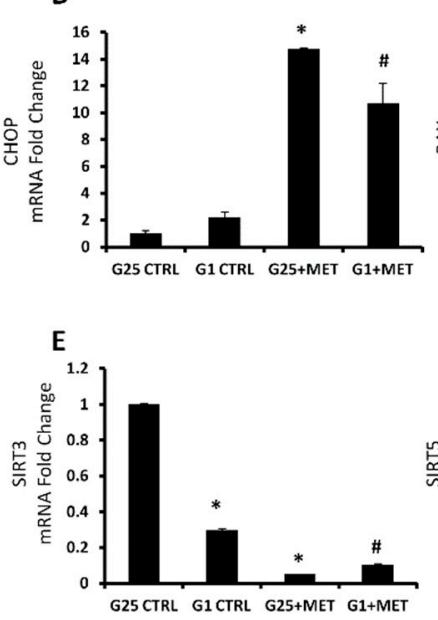

C
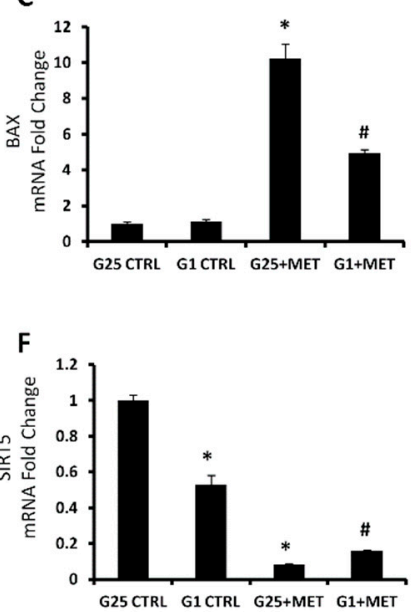

Figure 3. MRNA expression of HO-1 (A), CHOP (B), BAX (C), SIRT1 (D), SIRT3 (E), and SIRT5 (F), of control cells with $25 \mathrm{mM}$ glucose (G25 CTRL), control cells with $1 \mathrm{mM}$ glucose (G1 CTRL), G25 treated with $10 \mathrm{mM}$ metformin (G25 + MET), and G1 treated with $10 \mathrm{mM}$ metformin (G1 + MET). Results are mean $\pm \mathrm{SD},{ }^{*} p<0.05$ vs. G25 CTRL, ${ }^{*} p<0.05$ vs. G1 CTRL.

\subsection{Metformin Enhances the Apoptosis Rate of DU145 in the Presence of a Selective HO-1 Activity Inhibitor}

The apoptosis of DU145 cells was measured using Annexin V staining and flow cytometry analysis after $12 \mathrm{~h}$ of treatment. As shown in Figure 4, in both concentrations of glucose, the rate of apoptotic 
DU145 cells was significantly increased after treatment with MET. The co-treatment with a selective inhibitor of HO-1 activity (VP1347) caused a strong enhancement of apoptosis levels. The treatment with VP1347 alone did not demonstrate significant differences to the untreated control. The decreased level of live cells was more evident in the co-treatment group, indicating a synergistic effect (G1 CDI = $0.90 ; \mathrm{G} 25 \mathrm{CDI}=0.95)$ between MET and VP1347.
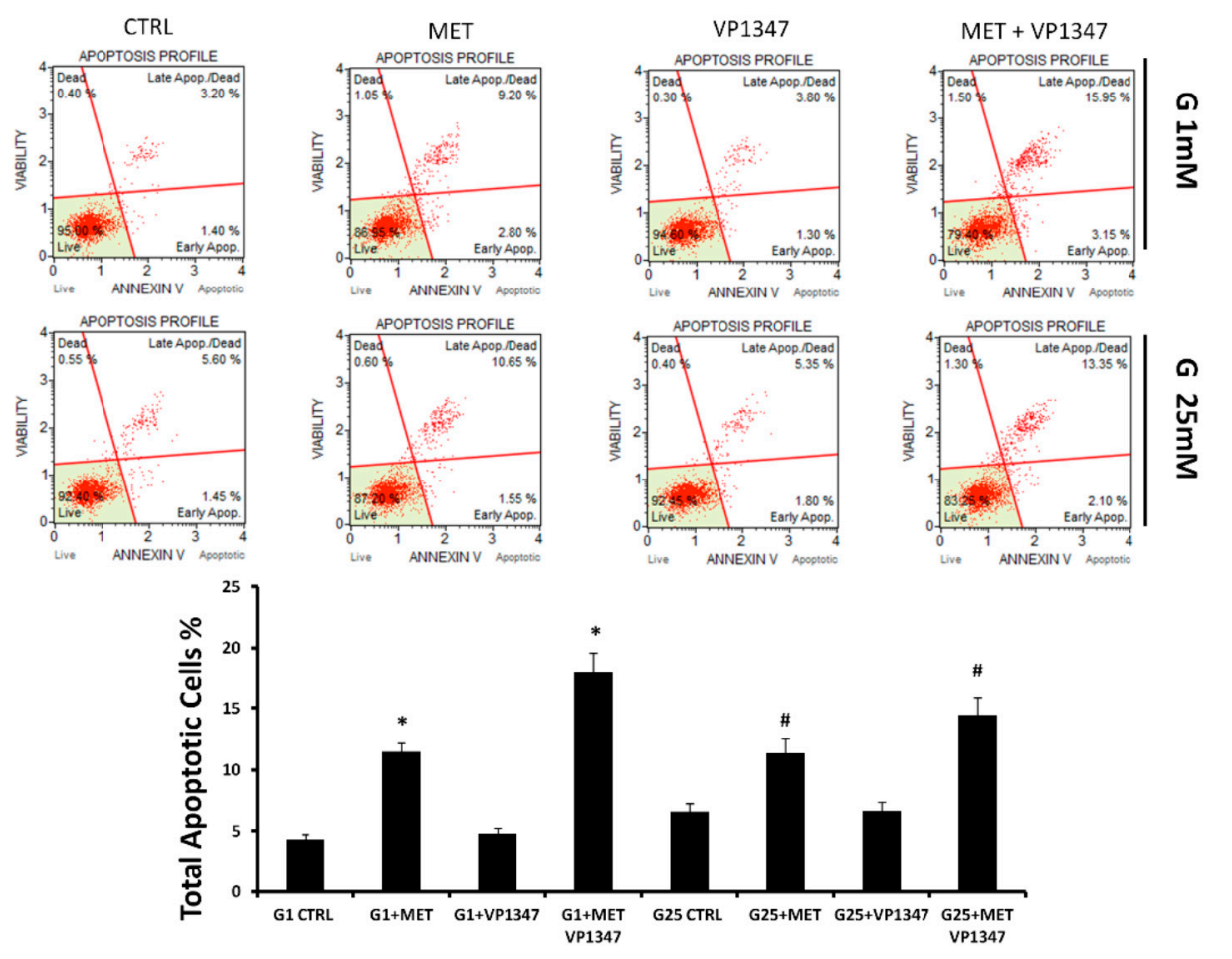

Figure 4. Effect of metformin and HO-1 activity inhibitor VP1347 on DU145 cells apoptosis. Cells were incubated with $1 \mathrm{mM}$ glucose (G1) or $25 \mathrm{mM}$ glucose (G25) in the presence and absence of $10 \mathrm{mM}$ metformin (MET) and $10 \mu \mathrm{M}$ VP1347 for $12 \mathrm{~h}$. Apoptosis was evaluated by cytometry, using the Muse Annexin V and Dead Cell Assay Kit. The graph showed the total apoptotic cells percentage in the different groups. * $p<0.05$ vs. G1 CTRL, ${ }^{\#} p<0.05$ vs. G25 CTRL.

\subsection{Effect of Metformin on Oxidative Stress Regulation Pathway}

At the $1 \mathrm{mM}$ glucose concentration, MET treatment caused a significant decrease of glutathione (GSH) levels compared to the control, especially when combined with VP1347. The treatment with VP1347 alone was not able to reduce the GSH levels. In the presence of the highest concentration of glucose, all treatments showed a reduction of GSH levels without difference within the groups (Figure 5A). TIGAR and Gamma-Glutamylcysteine Synthetase (GCLC) mRNA expression was measured after $6 \mathrm{~h}$ of treatment with MET and VP1347 in both concentrations of glucose (Figure 5B,C). At the $1 \mathrm{mM}$ glucose concentration, TIGAR levels were significantly reduced when treated with MET and VP1347, used alone or in combination, compared to the control. GCLC mRNA expression showed a marked increase only in the group treated with metformin. At high glucose concentration, TIGAR levels were strongly reduced in the presence of MET and VP1347, particularly when used as co-treatment. GCLC levels were decreased in all treated groups compared to the control.

\subsection{Effect of Metformin and HO-1 Activity Inhibitor on ROS Production}

The quantitative measurement of cells undergoing oxidative stress was evaluated by cytometry, using the Muse Oxidative Stress Kit after a $6 \mathrm{~h}$ treatment with MET and VP1347. As shown in Figure 6, in both concentrations of glucose, a positive ROS level was notably increased after MET and VP1347 administration 
compared to the control. The decrease of ROS M1 values was more evident in the co-treatment group, indicating a synergistic effect $(\mathrm{G} 1 \mathrm{CDI}=0.92 ; \mathrm{G} 25 \mathrm{CDI}=0.86)$ between MET and VP1347.

A
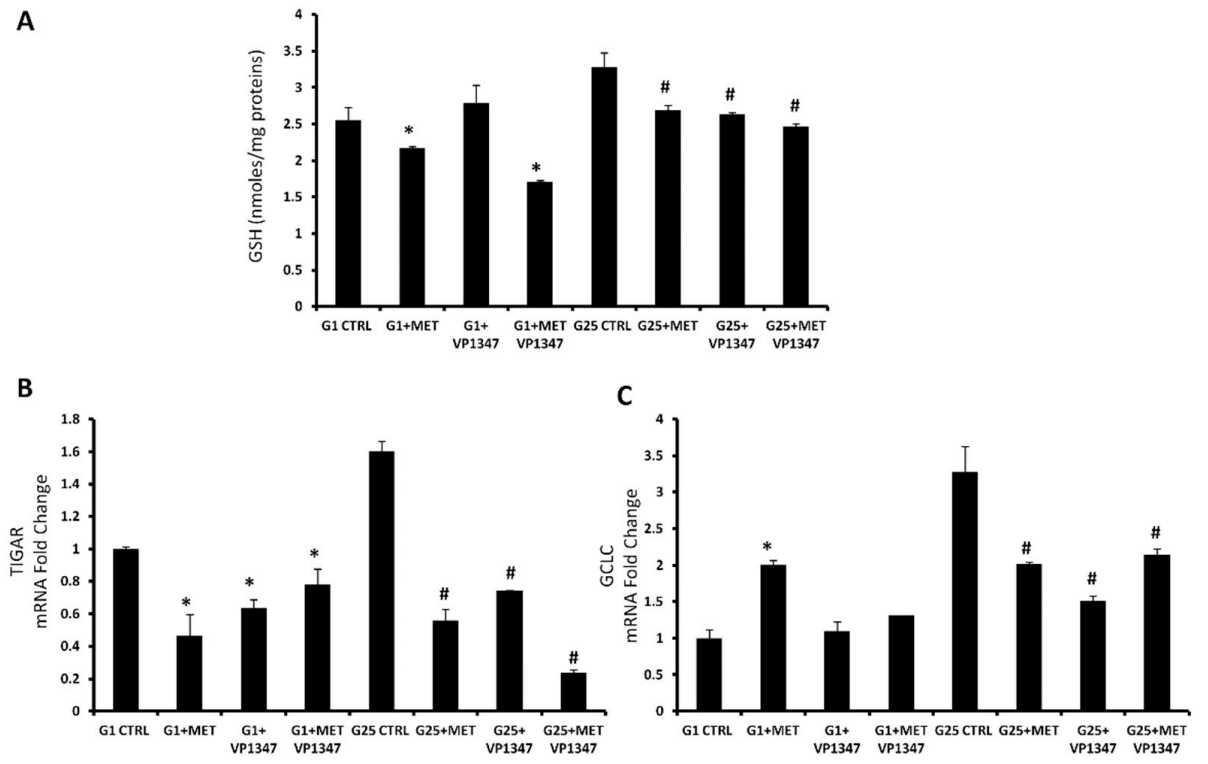

Figure 5. Metformin regulates oxidative stress pathway. (A) Thiol groups in DU145 cells treated for $24 \mathrm{~h}$ with $10 \mathrm{mM}$ metformin and $10 \mathrm{uM}$ VP1347. Thiol groups are expressed as nmol/mg protein. Values represent the means $\pm \mathrm{SD}$ of three experiments performed in triplicate. ${ }^{*} p<0.05$, significant result vs. untreated DU145 cells. (B,C) MRNA expression of TIGAR and GCLC of control cells with $25 \mathrm{mM}$ glucose (G25), control cells with $1 \mathrm{mM}$ glucose (G1), in the presence and absence of $10 \mathrm{mM}$ metformin (MET) and $10 \mu \mathrm{M}$ VP1347 for $6 \mathrm{~h}$. Results are mean $\pm \mathrm{SD},{ }^{*} p<0.05$ vs. G25 CTRL, ${ }^{*} p<0.05$ vs. G1 CTRL.
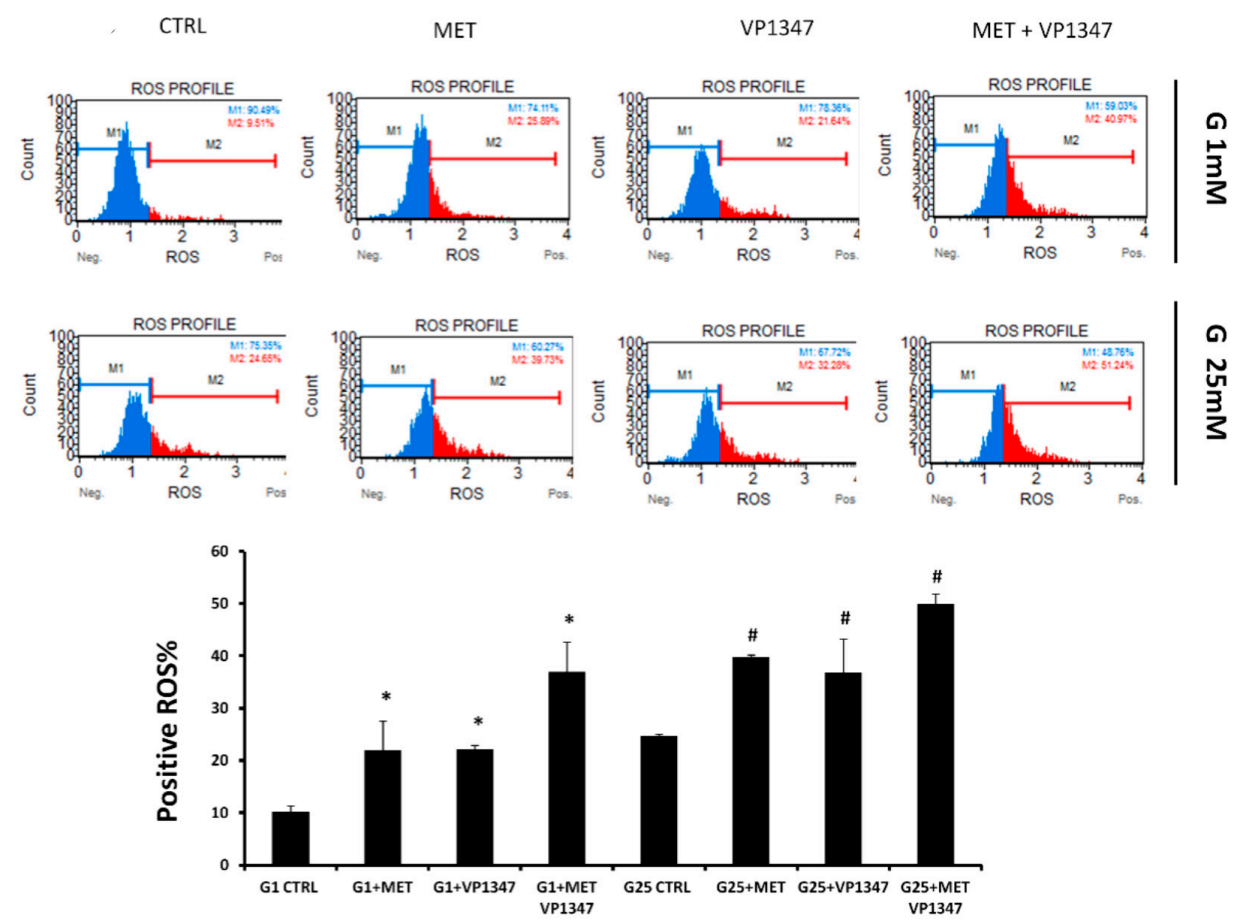

Figure 6. Effect of Metformin and HO-1 activity inhibitor VP1347 on DU145 cells ROS production. Cells were incubated with $1 \mathrm{mM}$ glucose (G1) or $25 \mathrm{mM}$ glucose (G25) in the presence and absence of $10 \mathrm{mM}$ metformin (MET) and $10 \mu \mathrm{M}$ VP1347 for $6 \mathrm{~h}$. The quantitative measurement of cells undergoing oxidative stress was evaluated by cytometry, using the Muse Oxidative Stress Kit. The graph showed the positive ROS percentage in the different groups. ${ }^{*} p<0.05$ vs. G1 CTRL, ${ }^{*} p<0.05$ vs. G25 CTRL. 


\section{Discussion}

In diabetic patients, metformin decreases plasma glucose concentration mainly by lowering hepatic gluconeogenesis and glucose output. This effect is followed by an increase in glucose uptake and the amelioration of insulin resistance [51]. MET works by targeting the enzyme AMPK (AMP activated protein kinase), which induces muscles to take up glucose from the blood. A recent breakthrough has found the upstream regulator of AMPK to be a protein kinase known as LKB1, a well-recognized tumor suppressor [52].

AMP-activated protein kinase (AMPK) activators have been in use for many years to treat type 2 diabetes, but recent data demonstrate that these compounds can inhibit AKT-derived pro-survival effects and induce apoptosis in cancer cells [53].

Several data suggest that MET, an AMPK inducer, could protect from cancer and inhibit breast and glial tumor cell proliferation $[52,54,55]$ through inhibition of the mitochondrial complex I activity and cellular respiration. An essential role of the electron transport chain in cell proliferation has been reported, due to its ability to enable the biosynthesis of aspartate, a proteinogenic amino acid and a precursor in purine and pyrimidine synthesis [56].

In this study, we show that MET not only is a very potent inhibitor of human prostate cancer cell growth, but its effect, in vitro, is potentiated by low glucose treatment and HO-1 activity inhibition.

Although many studies have shown the antineoplastic properties of MET, the mechanisms of action have not been clearly defined yet. As an anticancer agent, MET weakly induces cancer cell apoptosis. However, as shown in Figure 2, under cell culture conditions with low glucose, MET decreases cell proliferation. Starvation from glutamine or glucose for short periods resulted in cell cycle arrest and apoptosis induction by means of reactive oxygen species generation and mitochondrial dysfunction [57,58].

Glucose deprivation has been previously shown to increase MET-induced cell death in cancer cells $[59,60]$.

Glucose deprivation, a cell condition that occurs in solid tumors, activates the unfolded protein response (UPR), which allows the cell to survive under stress conditions [61].

Cancer cells in solid tumors are not supplied sufficient glucose because they are often distant from blood vessels. Adaptive response mechanisms are required for cancer cells to survive in the tumor microenvironment. The UPR in cancer cells plays an important role in their survival and results in tumor malignancies and antitumor drug resistance [62]. If cancer cells have no adaptive response, such as the UPR, activated by endoplasmic reticulum (ER) stress, they would not be able to escape death under glucose deprivation conditions [63].

The acute increase of $C H O P$ expression leads to activation of the mitochondria-mediated apoptosis pathway [64]. Therefore, ER stress-dependent apoptosis has been recently reported as a promising therapeutic pathway to target for inducing cancer cell death [65].

Previous studies have shown that metformin induces ER stress and UPR-related genes and inhibited cancer cell proliferation in a dose-dependent manner [66-68]. Aside from IRE1a, PERK, ATF6a, and CHOP regulation, ER stress has been associated with HO-1 induction, which represents a cytoprotective adaptive response to survive stringent conditions [69].

Previously, it has also been reported that the high expression of HO-1 is associated with tumor invasiveness and poor clinical outcome in non-small cell lung cancer patients [16].

Our previous studies showed that the chemotherapeutic drugs, carfilzomib and bortezomib, both increased HO-1 protein and gene expression via the activation of the UPR response, triggered by ER stress [17,70]. As shown in Figure 3, although glucose deprivation already increased HO-1 levels, MET significantly further induced HO-1, CHOP, and BAX mRNA levels, suggesting metformin can induce ER stress and cell apoptosis.

Sirtuins are homologs of the yeast SIR2 gene, and their function as regulators in a wide range of biological processes is mostly associated with a nicotinamide adenine dinucleotide (NAD+)-dependent deacetylation [71]. Recent studies have shown that seven sirtuins (SIRT 1-7) are linked to tumor 
growth regulation. Tumor suppression is associated with upregulation of SIRT1 levels, whereas SIRT3 and SIRT5 act differently as tumor promoters [72-74]. DNA damage, exerted by anti-proliferative drugs and the consequent increase of oxidative stress, could induce the expression of transcription factor E2F1, which increases the transcription of SIRT1 and other several apoptotic proteins [75]. Our results showed that MET treatment, both in the presence of $25 \mathrm{mM}$ and $1 \mathrm{mM}$ glucose concentration, increased levels of SIRT1 mRNA, as a demonstration of its anti-proliferative effect [76-78]. SIRT3 and SIRT5 are localized to mitochondria and, as previously published, metformin primarily acts through the mitochondrial respiratory chain inhibition $[79,80]$. Dysfunctional mitochondria probably represent the main cause of the observed decrease of sirtuins 3 and 5 mRNA in prostate cancer cells [71,81-83].

In this study, we evaluated MET-induced apoptosis in prostate cancer cells, using Annexin cytometry analysis. As shown in Figure 4, MET induced apoptosis in prostate cancer cells and, consistently with previous published results [17,84], HO-1 activity inhibition was able to further increase the cytotoxic effect induced by metformin in DU145 cells, indicating a synergistic effect between the two drugs.

HO-1 represents the inducible isoform of one of the main cytoprotective systems against oxidative stress and inflammation $[23,85,86]$. When normal cells are exposed to stress conditions, HO- 1 induction is the physiological response in order to guarantee regulation of redox homeostasis. For this reason, an adequate expression of this protein is necessary to confer a basal protection against oxidative stress $[87,88]$. Cancer cells are often characterized by an overexpression of HO-1 and an enhancement of the cytoprotection systems [16,89-91]. It has been reported that metformin alters cellular responses to oxidative stress [92], and the direct activity on mitochondria leads to ROS promotion [30,93-95].

The combined treatment with MET and a selective HO-1 activity inhibitor, under cell culture conditions with low and high glucose, demonstrated a significant decrease of GSH levels, TIGAR, and GCLC mRNA levels. Several reports showed the key role of these factors in the oxidative stress management $[96,97]$. TIGAR is a protein involved in the switch from glycolysis to the pentose phosphate pathway that promotes the production of cellular nicotinamide adenine dinucleotide phosphate (NADPH) $[47,98,99]$. NADPH levels enhancement, caused by TIGAR upregulation, leads to an increased restoration of GSH [100]. On the contrary, it has been shown that TIGAR knockdown decreased GSH and NADPH production and increased the levels of ROS [101]. In order to confirm the loss of the physiological protection from oxidative stress, ensured by GSH, we measured the ROS level in the presence of MET and the selective HO-1 activity inhibitor. We observed a considerable increase of ROS levels after treatment with the combination of MET and the HO-1 activity inhibitor. These results suggest that HO-1 inhibition may enhance metformin cytotoxicity through triggering ER stress-associated apoptosis and that ROS is also involved in the activation of ER stress, as schematized in the Figure 7.

In conclusion, our study demonstrates that metformin suppressed prostate cancer growth in vitro and increased oxidative stress under low and high glucose conditions.

Our findings show that disrupting the antioxidant HO-1 activity, especially under low glucose concentration, could be an attractive approach to potentiate MET antineoplastic effects and could provide a biochemical basis for developing HO-1-targeting drugs against solid tumors.

Further investigation of metformin's molecular mechanism and targets will reveal its potential application as a monotherapy or part of a polytherapy associated with a clinically approved HO-1 inhibitor in cancer treatment. 


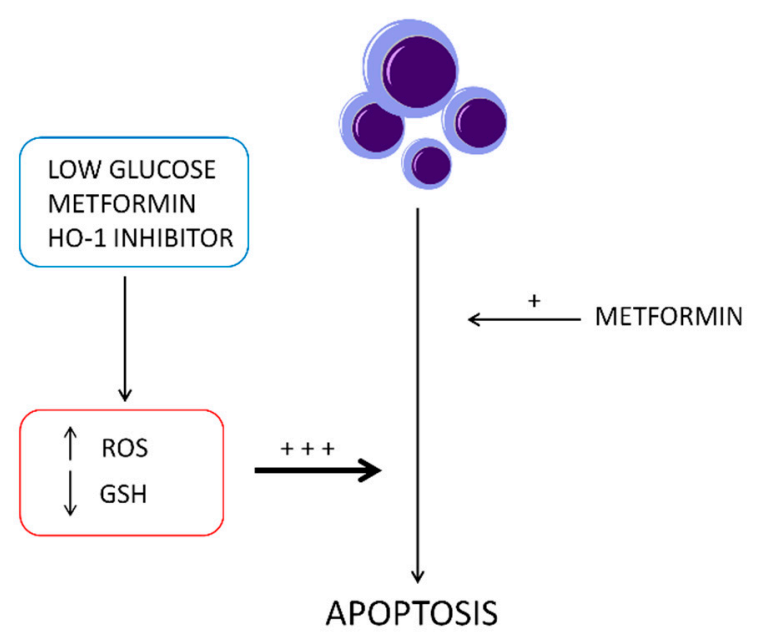

Figure 7. Schematic description of metformin and HO-1 activity inhibitor (VP1347) synergistic effect to induce apoptosis in DU145 cells.

\section{Materials and Methods}

\subsection{Cell Culture}

The human androgen-independent prostate cancer cell line DU145 was cultured in Dulbecco's modified Eagle's medium (DMEM) $4.5 \mathrm{~g} / \mathrm{L}$ glucose, supplemented with 10\% FBS, 1\% penicillin, and streptomycin at $37^{\circ} \mathrm{C}$ and $5 \% \mathrm{CO}_{2}$. The cells were purchased from American Type Culture Collection (Rockville, MD, USA).

\subsection{Cell Viability Assay}

DU145 cells were seeded at a concentration of $2 \times 10^{5}$ cells per well of a 96-well, flat-bottomed $200 \mu \mathrm{L}$ microplate. Cells were incubated at $37^{\circ} \mathrm{C}$ in a $5 \% \mathrm{CO}_{2}$ humidified atmosphere and maintained in the presence and absence of different concentrations $(3,5,10$, and $50 \mathrm{mM}$ ) of metformin (Sigma Chemical Co., St Louis, MO, USA) for $24 \mathrm{~h}$. Three hours before the end of the treatment time, $20 \mu \mathrm{L}$ of 0.5\% 3-(4,5-dimethylthiazol-2-yl)-2,5-diphenyltetrazolium bromide (MTT) in phosphate-buffered saline (PBS) was added to each microwell. After incubation with the reagent, the supernatant was removed and replaced with $100 \mu \mathrm{L}$ DMSO to dissolve the formazan crystals produced. The amount of formazan is proportional to the number of viable cells present. The optical density was measured using a microplate spectrophotometer reader (Synergy HT, BioTek) at $\lambda=570 \mathrm{~nm}$.

\subsection{Real-Time Monitoring of Proliferation}

Real-time monitoring of cell proliferation was performed using the xCELLigence RTCA DP system [102]. E-plate 16, used with the xCELLigence system, is a single-use 16-well cell culture plate with bottom surfaces covered with microelectrode sensors $\left(0.2 \mathrm{~cm}^{2}\right.$ well surface area; $243 \pm 5 \mu \mathrm{L}$ maximum volume). Real-time changes in electrical impedance were measured using the gold microelectrodes and expressed as cell index", defined as (Rn-Rb)/15, where Rb is the background impedance and $\mathrm{Rn}$ is the impedance of the well with cells. Negative control groups (wells containing $200 \mu \mathrm{L}$ culture medium without cells with cell index values around 0 ) were tested in every experiment; however, they were not shown in figures in order to simplify the representations. Before seeding cells into E-plate 16, the background impedance was measured after the addition of $100 \mu \mathrm{L}$ medium and a $30 \mathrm{~min}$ incubation period at room temperature. Following the seeding of the appropriate number of cells into the wells, the plate incubated at room temperature for $30 \mathrm{~min}$ in order to allow cell settling. Cell proliferation was monitored every $30 \mathrm{~min}$ for $48 \mathrm{~h}$. 


\subsection{Oxidative Stress Assay}

The quantitative measurement of cellular populations undergoing oxidative stress was performed using the Muse Oxidative Stress Kit (Merck Millipore, Billerica, MA, USA), according to the manufacturer's instructions. This assay utilizes dihydroethidium (DHE), which is cell membrane-permeable and, upon reaction with superoxide anions, undergoes oxidation to form DNA-binding fluorophore. The kit determines the percentage of cells that are negative [ROS(-)] and positive $[\operatorname{ROS}(+)]$ for reactive oxygen species. Briefly, after $6 \mathrm{~h}$ of treatment, $1 \times 10^{6}$ cells $/ \mathrm{mL}$ were harvested, washed with PBS, and then incubated in the dark at $37^{\circ} \mathrm{C}$ for 30 min with the Muse Oxidative Stress Reagent working solution, which contained DHE. The count and percentage of cells undergoing oxidative stress were quantified using the Muse Cell Analyzer and Muse analysis software (Merck Millipore, USA).

\subsection{Annexin V Assay}

Apoptosis determination by Annexin V staining was carried out using Muse Cell Analyzer with the kit provided by the manufacturer Merck Millipore. In brief, $1 \times 10^{6}$ cells were seeded in six-well plates and, after overnight adherence, they were treated and incubated with $10 \mathrm{mM}$ MET and VP1347, 1-\{4-[(4-bromobenzyl)oxy]phenyl\}-2-(1H-imidazol-1-yl)ethanol, a HO-1 activity non-competitive inhibitor, that binds to the complex enzyme/substrate. The compound was synthesized by Salerno et al. from the University of Catania as previously described [103].

It presented an $\mathrm{IC}_{50}<1 \mu \mathrm{M}$ on HO-1 and showed a $>100$ selectivity toward HO-2. After $12 \mathrm{~h}$, the cells were detached by trypsinization, centrifuged, and resuspended in PBS. Cell suspension $(100 \mu \mathrm{L})$ was added with $100 \mu \mathrm{L}$ of Annexin V reagent and incubated for $20 \mathrm{~min}$ at room temperature, after which the cells were analyzed for apoptosis.

\subsection{RSH Evaluation}

For total thiol groups (RSH) determination, DU145 cells were cultured for $24 \mathrm{~h}$ in the presence or absence of $10 \mathrm{mM}$ MET and VP1347. Determination of RSH was performed as previously described [104]. In short, this spectrophotometric assay is based on the reaction of thiol groups with 2,2-dithio-bis-nitrobenzoic acid (DTNB) in absolute ethanol to give a colored compound absorbing at $\lambda=412 \mathrm{~nm}$. We then carried out the removal of proteins with an excess of absolute ethanol, followed by centrifugation at $3000 \times g$ for $10 \mathrm{~min}$ at room temperature. Each value represents the mean $\pm \mathrm{SD}$ of three experimental determinations for each sample. Results were expressed as nanomoles per milligram of protein.

\subsection{RNA Extraction and $q R T-P C R$}

RNA was extracted by Trizol reagent (Invitrogen, Carlsbad, CA, USA). First strand cDNA was then synthesized with Applied Biosystem (Foster City, CA, USA) reverse transcription reagent. Quantitative real-time PCR was performed in Step One Fast Real-Time PCR System Applied Biosystems, using the SYBR Green PCR MasterMix (Life Technologies, Monza, Italy). The specific PCR products were detected by the fluorescence of SYBR Green, the double stranded DNA binding dye. The relative mRNA expression level was calculated by the threshold cycle $(\mathrm{Ct})$ value of each PCR product and normalized with that of actin by using a comparative $2^{-\Delta \Delta C t}$ method.

\subsection{Statistical Analysis}

Statistical significance $(p<0.05)$ of differences between experimental groups was determined by the Fisher method for analysis of multiple comparisons. For comparison between treatment groups, the null hypothesis was tested by either single-factor analysis of variance (ANOVA) for multiple groups, or the unpaired $t$-test for two groups, and the data are presented as mean $\pm \mathrm{SD}$. 
The coefficient of drug interaction $(\mathrm{CDI})$ has been calculated as follows: $\mathrm{CDI}=\mathrm{AB} /(\mathrm{A} \times \mathrm{B})$. According to the values of each group, $\mathrm{AB}$ is the ratio of the combination groups to control group; $\mathrm{A}$ or $B$ is the ratio of the single agent group to control group. Thus, CDI value $<1,=1$, or $>1$ indicates that the drugs are synergistic, additive, or antagonistic, respectively.

Author Contributions: M.R., V.Z., L.V., I.B., and V.S., conceptualization, writing original draft preparation; M.R., V.Z., and G.C., investigation and formal analysis; V.S., V.P., L.S., and G.R., funding acquisition and synthesis of the inhibitor; G.L.V., L.V., resources and writing-review and editing; L.V., supervision and project administration.

Funding: This work was supported by Research Funding for University of Catania, Italy (Piano per la Ricerca, project code 57722172111).

Conflicts of Interest: The authors declare no conflict of interest.

\section{References}

1. Abraham, N.G.; Kappas, A. Pharmacological and Clinical Aspects of Heme Oxygenase. Pharmacol. Rev. 2008, 60, 79-127. [CrossRef]

2. Foresti, R.; Green, C.J; Motterlini, R. Generation of Bile Pigments by Haem Oxygenase: A Refined Cellular Strategy in Response to Stressful Insults. Biochem. Soc. Symp. 2004, 177-192. [CrossRef]

3. Pittala, V.; Vanella, L.; Salerno, L.; Romeo, G.; Marrazzo, A.; di Giacomo, C.; Sorrenti, V. Effects of Polyphenolic Derivatives on Heme Oxygenase-System in Metabolic Dysfunctions. Curr. Med. Chem. 2018, 25, 1577-1595. [CrossRef]

4. Vanella, L.; Barbagallo, I.; Tibullo, D.; Forte, S.; Zappala, A.; Volti, G.L. The Non-Canonical Functions of the Heme Oxygenases. Oncotarget 2016, 7, 69075-69086. [CrossRef] [PubMed]

5. Converso, D.P.; Taille, C.; Carreras, M.C.; Jaitovich, A.; Poderoso, J.J.; Boczkowski, J. Ho-1 Is Located in Liver Mitochondria and Modulates Mitochondrial Heme Content and Metabolism. FASEB J. 2006, 20, 1236-1238. [CrossRef] [PubMed]

6. Kim, H.P.; Wang, X.; Galbiati, F.; Ryter, S.W.; Choi, A.M. Caveolae Compartmentalization of Heme Oxygenase-1 in Endothelial Cells. FASEB J. 2004, 18, 1080-1089. [CrossRef]

7. Rodella, L.F.; Vanella, L.; Peterson, S.J.; Drummond, G.; Rezzani, R.; Falck, J.R.; Abraham, N.G. Heme Oxygenase-Derived Carbon Monoxide Restores Vascular Function in Type 1 Diabetes. Drug Metab. Lett. 2008, 2, 290-300. [CrossRef]

8. Vanella, L.; Sanford, C., Jr; Kim, D.H.; Abraham, N.G.; Ebraheim, N. Oxidative Stress and Heme Oxygenase-1 Regulated Human Mesenchymal Stem Cells Differentiation. Int. J. Hypertens. 2012, 2012, 890671. [CrossRef] [PubMed]

9. Liu, L.; Puri, N.; Raffaele, M.; Schragenheim, J.; Singh, S.P.; Bradbury, J.A.; Bellner, L.; Vanella, L.; Zeldin, D.C.; Cao, J.; et al. Ablation of Soluble Epoxide Hydrolase Reprogram White Fat to Beige-Like Fat through an Increase in Mitochondrial Integrity, Ho-1-Adiponectin in Vitro and in Vivo. Prostaglandins Other Lipid Mediat. 2018, 138, 1-8. [CrossRef]

10. Pittala, V.; Vanella, L.; Salerno, L.; di Giacomo, C.; Acquaviva, R.; Raffaele, M.; Romeo, G.; Modica, M.N.; Prezzavento, O.; Sorrenti, V. Novel Caffeic Acid Phenethyl Ester (Cape) Analogues as Inducers of Heme Oxygenase-1. Curr. Pharm. Des. 2017, 23, 2657-2664. [CrossRef] [PubMed]

11. Raffaele, M.; Volti, G.L.; Barbagallo, I.A.; Vanella, L. Therapeutic Efficacy of Stem Cells Transplantation in Diabetes: Role of Heme Oxygenase. Front. Cell Dev. Biol. 2016, 4, 80. [CrossRef]

12. Stec, D.E.; John, K.; Trabbic, C.J.; Luniwal, A.; Hankins, M.W.; Baum, J.; Hinds, T.D., Jr. Bilirubin Binding to Pparalpha Inhibits Lipid Accumulation. PLoS ONE 2016, 11, e0153427. [CrossRef]

13. Pittala, V.; Salerno, L.; Romeo, G.; Acquaviva, R.; di Giacomo, C.; Sorrenti, V. Therapeutic Potential of Caffeic Acid Phenethyl Ester (Cape) in Diabetes. Curr. Med. Chem. 2018, 25, 4827-4836. [CrossRef]

14. Dey, S.; Sayers, C.M.; Verginadis, I.I.; Lehman, S.L.; Cheng, Y.; Cerniglia, G.J.; Tuttle, S.W.; Feldman, M.D.; Zhang, P.J.; Fuchs, S.Y.; et al. Atf4-Dependent Induction of Heme Oxygenase 1 Prevents Anoikis and Promotes Metastasis. J. Clin. Investig. 2015, 125, 2592-2608. [CrossRef] [PubMed]

15. Song, J.; Zhang, X.; Liao, Z.; Liang, H.; Chu, L.; Dong, W.; Zhang, X.; Ge, Q.; Liu, Q.; Fan, P.; et al. 14-3-3zeta Inhibits Heme Oxygenase-1 (Ho-1) Degradation and Promotes Hepatocellular Carcinoma Proliferation: Involvement of Stat3 Signaling. J. Exp. Clin. Cancer Res. 2019, 38, 3. [CrossRef] 
16. Nitti, M.; Piras, S.; Marinari, U.M.; Moretta, L.; Pronzato, M.A.; Furfaro, A.L. Ho-1 Induction in Cancer Progression: A Matter of Cell Adaptation. Antioxidants 2017, 6, 29. [CrossRef]

17. Barbagallo, I.; Giallongo, C.; Volti, G.L.; Distefano, A.; Camiolo, G.; Raffaele, M.; Salerno, L.; Pittala, V.; Sorrenti, V.; Avola, R.; et al. Heme Oxygenase Inhibition Sensitizes Neuroblastoma Cells to Carfilzomib. Mol. Neurobiol. 2019, 56, 1451-1460. [CrossRef]

18. Tibullo, D.; Barbagallo, I.; Giallongo, C.; la Cava, P.; Parrinello, N.; Vanella, L.; Stagno, F.; Palumbo, G.A.; Volti, G.L.; di Raimondo, F. Nuclear Translocation of Heme Oxygenase-1 Confers Resistance to Imatinib in Chronic Myeloid Leukemia Cells. Curr. Pharm. Des. 2013, 19, 2765-2770. [CrossRef]

19. Salerno, L.; Romeo, G.; Modica, M.N.; Amata, E.; Sorrenti, V.; Barbagallo, I.; Pittala, V. Heme Oxygenase-1: A New Druggable Target in the Management of Chronic and Acute Myeloid Leukemia. Eur. J. Med. Chem. 2017, 142, 163-178. [CrossRef]

20. Schaefer, B.; Behrends, S. Translocation of Heme Oxygenase-1 Contributes to Imatinib Resistance in Chronic Myelogenous Leukemia. Oncotarget 2017, 8, 67406-67421. [CrossRef] [PubMed]

21. Greish, K.F.; Salerno, L.; Al Zahrani, R.; Amata, E.; Modica, M.N.; Romeo, G.; Marrazzo, A.; Prezzavento, O.; Sorrenti, V.; Rescifina, A.; et al. Novel Structural Insight into Inhibitors of Heme Oxygenase-1 (Ho-1) by New Imidazole-Based Compounds: Biochemical and in Vitro Anticancer Activity Evaluation. Molecules 2018, 23, 1209. [CrossRef]

22. Sorrenti, V.; Pittala, V.; Romeo, G.; Amata, E.; Dichiara, M.; Marrazzo, A.; Turnaturi, R.; Prezzavento, O.; Barbagallo, I.; Vanella, L.; et al. Targeting Heme Oxygenase-1 with Hybrid Compounds to Overcome Imatinib Resistance in Chronic Myeloid Leukemia Cell Lines. Eur. J. Med. Chem. 2018, 158, 937-950. [CrossRef]

23. Jozkowicz, A.; Was, H.; Dulak, J. Heme Oxygenase-1 in Tumors: Is It a False Friend? Antioxid. Redox Signal. 2007, 9, 2099-2117. [CrossRef]

24. Florczyk, U.; Golda, S.; Zieba, A.; Cisowski, J.; Jozkowicz, A.; Dulak, J. Overexpression of Biliverdin Reductase Enhances Resistance to Chemotherapeutics. Cancer Lett. 2011, 300, 40-47. [CrossRef]

25. Banerjee, P.; Basu, A.; Wegiel, B.; Otterbein, L.E.; Mizumura, K.; Gasser, M.; Waaga-Gasser, A.M.; Choi, A.M.; Pal, S. Heme Oxygenase-1 Promotes Survival of Renal Cancer Cells through Modulation of Apoptosis- and Autophagy-Regulating Molecules. J. Biol. Chem. 2012, 287, 32113-32123. [CrossRef]

26. Zingales, V.; Distefano, A.; Raffaele, M.; Zanghi, A.; Barbagallo, I.; Vanella, L. Metformin: A Bridge between Diabetes and Prostate Cancer. Front. Oncol. 2017, 7, 243. [CrossRef]

27. Hankinson, S.J.; Fam, M.; Patel, N.N. A Review for Clinicians: Prostate Cancer and the Antineoplastic Properties of Metformin. Urol. Oncol. 2017, 35, 21-29. [CrossRef]

28. Wright, J.L.; Stanford, J.L. Metformin Use and Prostate Cancer in Caucasian Men: Results from a Population-Based Case-Control Study. Cancer Causes Control 2009, 20, 1617-1622. [CrossRef]

29. Lu, C.C.; Chiang, J.H.; Tsai, F.J.; Hsu, Y.M.; Juan, Y.N.; Yang, J.S.; Chiu, H.Y. Metformin Triggers the Intrinsic Apoptotic Response in Human Ags Gastric Adenocarcinoma Cells by Activating Ampk and Suppressing Mtor/Akt Signaling. Int. J. Oncol. 2019, 54, 1271-1281. [CrossRef]

30. Andrzejewski, S.; Gravel, S.P.; Pollak, M.; St-Pierre, J. Metformin Directly Acts on Mitochondria to Alter Cellular Bioenergetics. Cancer Metab. 2014, 2, 12. [CrossRef]

31. Cantrell, L.A.; Zhou, C.; Mendivil, A.; Malloy, K.M.; Gehrig, P.A.; Bae-Jump, V.L. Metformin Is a Potent Inhibitor of Endometrial Cancer Cell Proliferation-Implications for a Novel Treatment Strategy. Gynecol. Oncol. 2010, 116, 92-98. [CrossRef]

32. Ben Sahra, I.; Laurent, K.; Loubat, A.; Giorgetti-Peraldi, S.; Colosetti, P.; Auberger, P.; Tanti, J.F.; le Marchand-Brustel, Y.; Bost, F. The Antidiabetic Drug Metformin Exerts an Antitumoral Effect in Vitro and in Vivo through a Decrease of Cyclin D1 Level. Oncogene 2008, 27, 3576-3586. [CrossRef]

33. Clements, A.; Gao, B.; Yeap, S.H.; Wong, M.K.; Ali, S.S.; Gurney, H. Metformin in Prostate Cancer: Two for the Price of One. Ann. Oncol. 2011, 22, 2556-2560. [CrossRef] [PubMed]

34. Richards, K.A.; Liou, J.I.; Cryns, V.L.; Downs, T.M.; Abel, E.J.; Jarrard, D.F. Metformin Use Is Associated with Improved Survival for Patients with Advanced Prostate Cancer on Androgen Deprivation Therapy. J. Urol. 2018, 200, 1256-1263. [CrossRef]

35. Sarmento-Cabral, A.; Fernando, L.; Gahete, M.D.; Castano, J.P.; Luque, R.M. Metformin Reduces Prostate Tumor Growth, in a Diet-Dependent Manner, by Modulating Multiple Signaling Pathways. Mol. Cancer Res. 2017, 15, 862-874. [CrossRef] 
36. Sharma, A.; Bandyopadhayaya, S.; Chowdhury, K.; Sharma, T.; Maheshwari, R.; Das, A.; Chakrabarti, G.; Kumar, V.; Mandal, C.C. Metformin Exhibited Anticancer Activity by Lowering Cellular Cholesterol Content in Breast Cancer Cells. PLoS ONE 2019, 14, e0209435. [CrossRef]

37. Hindler, K.; Cleeland, C.S.; Rivera, E.; Collard, C.D. The Role of Statins in Cancer Therapy. Oncologist 2006, 11, 306-315. [CrossRef]

38. Babcook, M.A.; Sramkoski, R.M.; Fujioka, H.; Daneshgari, F.; Almasan, A.; Shukla, S.; Nanavaty, R.R.; Gupta, S. Combination Simvastatin and Metformin Induces G1-Phase Cell Cycle Arrest and Ripk1- and Ripk3-Dependent Necrosis in C4-2b Osseous Metastatic Castration-Resistant Prostate Cancer Cells. Cell Death Dis. 2014, 5, e1536. [CrossRef]

39. Wang, Z.S.; Huang, H.R.; Zhang, L.Y.; Kim, S.; He, Y.; Li, D.L.; Farischon, C.; Zhang, K.; Zheng, X.; Du, Z.Y.; et al. Mechanistic Study of Inhibitory Effects of Metformin and Atorvastatin in Combination on Prostate Cancer Cells in Vitro and in Vivo. Biol. Pharm. Bull. 2017, 40, 1247-1254. [CrossRef]

40. Tran, L.N.K.; Kichenadasse, G.; Morel, K.L.; Lavranos, T.C.; Klebe, S.; Lower, K.M.; Ormsby, R.J.; Elliot, D.J.; Sykes, P.J. The Combination of Metformin and Valproic Acid Has a Greater Anti-Tumoral Effect on Prostate Cancer Growth in Vivo Than Either Drug Alone. In Vivo 2019, 33, 99-108. [CrossRef]

41. Cuyas, E.; Verdura, S.; Llorach-Pares, L.; Fernandez-Arroyo, S.; Joven, J.; Martin-Castillo, B.; Bosch-Barrera, J.; Brunet, J.; Nonell-Canals, A.; Sanchez-Martinez, M.; et al. Metformin Is a Direct Sirt1-Activating Compound: Computational Modeling and Experimental Validation. Front. Endocrinol. (Lausanne) 2018, 9, 657. [CrossRef] [PubMed]

42. Pusapati, R.V.; Daemen, A.; Wilson, C.; Sandoval, W.; Gao, M.; Haley, B.; Baudy, A.R.; Hatzivassiliou, G.; Evangelista, M.; Settleman, J. Mtorc1-Dependent Metabolic Reprogramming Underlies Escape from Glycolysis Addiction in Cancer Cells. Cancer Cell 2016, 29, 548-562. [CrossRef] [PubMed]

43. Granja, S.; Pinheiro, C.; Reis, R.M.; Martinho, O.; Baltazar, F. Glucose Addiction in Cancer Therapy: Advances and Drawbacks. Curr. Drug Metab. 2015, 16, 221-242. [CrossRef] [PubMed]

44. Bikas, A.; Jensen, K.; Patel, A.; Costello, J., Jr.; McDaniel, D.; Klubo-Gwiezdzinska, J.; Larin, O.; Hoperia, V.; Burman, K.D.; Boyle, L.; et al. Glucose-Deprivation Increases Thyroid Cancer Cells Sensitivity to Metformin. Endocr. Relat. Cancer 2015, 22, 919-932. [CrossRef]

45. Zordoky, B.N.; Bark, D.; Soltys, C.L.; Sung, M.M.; Dyck, J.R. The Anti-Proliferative Effect of Metformin in Triple-Negative Mda-Mb-231 Breast Cancer Cells Is Highly Dependent on Glucose Concentration: Implications for Cancer Therapy and Prevention. Biochim. Biophys. Acta 1840, 2014, 1943-1957. [CrossRef]

46. Li, P.D.; Liu, Z.; Cheng, T.T.; Luo, W.G.; Yao, J.; Chen, J.; Zou, Z.W.; Chen, L.L.; Ma, C.; Dai, X.F. Redox-Dependent Modulation of Metformin Contributes to Enhanced Sensitivity of Esophageal Squamous Cell Carcinoma to Cisplatin. Oncotarget 2017, 8, 62057-62068. [CrossRef] [PubMed]

47. Dodson, M.; Darley-Usmar, V.; Zhang, J. Cellular Metabolic and Autophagic Pathways: Traffic Control by Redox Signaling. Free Radic. Biol. Med. 2013, 63, 207-221. [CrossRef]

48. Buzzai, M.; Jones, R.G.; Amaravadi, R.K.; Lum, J.J.; DeBerardinis, R.J.; Zhao, F.; Viollet, B.; Thompson, C.B. Systemic Treatment with the Antidiabetic Drug Metformin Selectively Impairs P53-Deficient Tumor Cell Growth. Cancer Res. 2007, 67, 6745-6752. [CrossRef]

49. Gonnissen, A.; Isebaert, S.; McKee, C.M.; Muschel, R.J.; Haustermans, K. The Effect of Metformin and Gant61 Combinations on the Radiosensitivity of Prostate Cancer Cells. Int. J. Mol. Sci. 2017, 18, 399. [CrossRef]

50. Knowell, A.E.; Patel, D.; Morton, D.J.; Sharma, P.; Glymph, S.; Chaudhary, J. Id4 Dependent Acetylation Restores Mutant-P53 Transcriptional Activity. Mol. Cancer 2013, 12, 161. [CrossRef]

51. Salani, B.; del Rio, A.; Marini, C.; Sambuceti, G.; Cordera, R.; Maggi, D. Metformin, Cancer and Glucose Metabolism. Endocr. Relat. Cancer 2014, 21, R461-R471. [CrossRef]

52. Evans, J.M.; Donnelly, L.A.; Emslie-Smith, A.M.; Alessi, D.R.; Morris, A.D. Metformin and Reduced Risk of Cancer in Diabetic Patients. BMJ 2005, 330, 1304-1305. [CrossRef] [PubMed]

53. Mukhopadhyay, S.; Chatterjee, A.; Kogan, D.; Patel, D.; Foster, D.A. 5-Aminoimidazole-4-Carboxamide-1-Beta4-Ribofuranoside (Aicar) Enhances the Efficacy of Rapamycin in Human Cancer Cells. Cell Cycle 2015, 14, 3331-3339. [CrossRef]

54. Schneider, M.B.; Matsuzaki, H.; Haorah, J.; Ulrich, A.; Standop, J.; Ding, X.Z.; Adrian, T.E.; Pour, P.M. Prevention of Pancreatic Cancer Induction in Hamsters by Metformin. Gastroenterology 2001, 120, 1263-1270. [CrossRef] 
55. Zakikhani, M.; Dowling, R.; Fantus, I.G.; Sonenberg, N.; Pollak, M. Metformin Is an Amp Kinase-Dependent Growth Inhibitor for Breast Cancer Cells. Cancer Res. 2006, 66, 10269-10273. [CrossRef] [PubMed]

56. Birsoy, K.; Wang, T.; Chen, W.W.; Freinkman, E.; Abu-Remaileh, M.; Sabatini, D.M. An Essential Role of the Mitochondrial Electron Transport Chain in Cell Proliferation Is to Enable Aspartate Synthesis. Cell 2015, 162, 540-551. [CrossRef] [PubMed]

57. Visagie, M.H.; Mqoco, T.V.; Liebenberg, L.; Mathews, E.H.; Mathews, G.E.; Joubert, A.M. Influence of Partial and Complete Glutamine-and Glucose Deprivation of Breast-and Cervical Tumorigenic Cell Lines. Cell Biosci. 2015, 5, 37. [CrossRef] [PubMed]

58. Mukhopadhyay, S.; Saqcena, M.; Foster, D.A. Synthetic Lethality in Kras-Driven Cancer Cells Created by Glutamine Deprivation. Oncoscience 2015, 2, 807-808.

59. Menendez, J.A.; Oliveras-Ferraros, C.; Cufi, S.; Corominas-Faja, B.; Joven, J.; Martin-Castillo, B.; Vazquez-Martin, A. Metformin Is Synthetically Lethal with Glucose Withdrawal in Cancer Cells. Cell Cycle 2012, 11, 2782-2792. [CrossRef]

60. Saito, S.; Furuno, A.; Sakurai, J.; Sakamoto, A.; Park, H.R.; Shin-Ya, K.; Tsuruo, T.; Tomida, A. Chemical Genomics Identifies the Unfolded Protein Response as a Target for Selective Cancer Cell Killing During Glucose Deprivation. Cancer Res. 2009, 69, 4225-4234. [CrossRef]

61. Schroder, M.; Kaufman, R.J. The Mammalian Unfolded Protein Response. Annu. Rev. Biochem. 2005, 74, 739-789. [CrossRef] [PubMed]

62. Limonta, P.; Moretti, R.M.; Marzagalli, M.; Fontana, F.; Raimondi, M.; Marelli, M.M. Role of Endoplasmic Reticulum Stress in the Anticancer Activity of Natural Compounds. Int. J. Mol. Sci. 2019, 20, 961. [CrossRef] [PubMed]

63. Haga, N.; Saito, S.; Tsukumo, Y.; Sakurai, J.; Furuno, A.; Tsuruo, T.; Tomida, A. Mitochondria Regulate the Unfolded Protein Response Leading to Cancer Cell Survival under Glucose Deprivation Conditions. Cancer Sci. 2010, 101, 1125-1132. [CrossRef] [PubMed]

64. Xu, Z.; Bu, Y.; Chitnis, N.; Koumenis, C.; Fuchs, S.Y.; Diehl, J.A. Mir-216b Regulation of C-Jun Mediates Gadd153/Chop-Dependent Apoptosis. Nat. Commun. 2016, 7, 11422. [CrossRef] [PubMed]

65. Verfaillie, T.; Garg, A.D.; Agostinis, P. Targeting Er Stress Induced Apoptosis and Inflammation in Cancer. Cancer Lett. 2013, 332, 249-264. [CrossRef] [PubMed]

66. Salis, O.; Bedir, A.; Ozdemir, T.; Okuyucu, A.; Alacam, H. The Relationship between Anticancer Effect of Metformin and the Transcriptional Regulation of Certain Genes (Chop, Cav-1, Ho-1, Sgk-1 and Par-4) on Mcf-7 Cell Line. Eur. Rev. Med. Pharmacol. Sci. 2014, 18, 1602-1609.

67. Yang, J.; Wei, J.; Wu, Y.; Wang, Z.; Guo, Y.; Lee, P.; Li, X. Metformin Induces Er Stress-Dependent Apoptosis through Mir-708-5p/Nnat Pathway in Prostate Cancer. Oncogenesis 2015, 4, e158. [CrossRef]

68. Ma, L.; Wei, J.; Wan, J.; Wang, W.; Wang, L.; Yuan, Y.; Yang, Z.; Liu, X.; Ming, L. Low Glucose and Metformin-Induced Apoptosis of Human Ovarian Cancer Cells Is Connected to Ask1 Via Mitochondrial and Endoplasmic Reticulum Stress-Associated Pathways. J. Exp. Clin. Cancer Res. 2019, 38, 77. [CrossRef]

69. Li Volti, G.; Tibullo, D.; Vanella, L.; Giallongo, C.; di Raimondo, F.; Forte, S.; di Rosa, M.; Signorelli, S.S.; Barbagallo, I. The Heme Oxygenase System in Hematological Malignancies. Antioxid. Redox Signal. 2017, 27, 363-377. [CrossRef]

70. Tibullo, D.; Barbagallo, I.; Giallongo, C.; Vanella, L.; Conticello, C.; Romano, A.; Saccone, S.; Godos, J.; di Raimondo, F.; Volti, G.L. Heme Oxygenase-1 Nuclear Translocation Regulates Bortezomibinduced Cytotoxicity and Mediates Genomic Instability in Myeloma Cells. Oncotarget 2016, 7, 28868-28880. [CrossRef]

71. Onyango, P.; Celic, I.; McCaffery, J.M.; Boeke, J.D.; Feinberg, A.P. Sirt3, a Human Sir2 Homologue, Is an Nad-Dependent Deacetylase Localized to Mitochondria. Proc. Natl. Acad. Sci. USA 2002, 99, 13653-13658. [PubMed]

72. Liu, R.; Fan, M.; Candas, D.; Qin, L.; Zhang, X.; Eldridge, A.; Zou, J.X.; Zhang, T.; Juma, S.; Jin, C.; et al. Cdk1-Mediated Sirt3 Activation Enhances Mitochondrial Function and Tumor Radioresistance. Mol. Cancer Ther. 2015, 14, 2090-2102. [CrossRef] [PubMed]

73. Chen, X.; Xu, Z.; Zeng, S.; Wang, X.; Liu, W.; Qian, L.; Wei, J.; Yang, X.; Shen, Q.; Gong, Z.; et al. Sirt5 Downregulation Is Associated with Poor Prognosis in Glioblastoma. Cancer Biomark. 2019, 24, 449-459. [CrossRef]

74. Deng, C.X. Sirt1, Is It a Tumor Promoter or Tumor Suppressor? Int. J. Biol. Sci. 2009, 5, 147-152. 
75. Wang, C.; Chen, L.; Hou, X.; Li, Z.; Kabra, N.; Ma, Y.; Nemoto, S.; Finkel, T.; Gu, W.; Cress, W.D.; et al. Interactions between E2f1 and Sirt1 Regulate Apoptotic Response to DNA Damage. Nat. Cell Biol. 2006, 8 , 1025-1031. [CrossRef]

76. Liu, T.F.; McCall, C.E. Deacetylation by Sirt1 Reprograms Inflammation and Cancer. Genes Cancer 2013, 4, 135-147. [CrossRef] [PubMed]

77. Yi, J.; Luo, J. Sirt1 and P53, Effect on Cancer, Senescence and Beyond. Biochim. Biophys. Acta 1804, 2010, 1684-1689. [CrossRef]

78. Zhang, Y.G.; Cai, X.Q.; Chai, N.; Gu, Y.; Zhang, S.; Ding, M.L.; Cao, H.C.; Sha, S.M.; Yin, J.P.; Li, M.B.; et al. Sirt1 Is Reduced in Gastric Adenocarcinoma and Acts as a Potential Tumor Suppressor in Gastric Cancer. Gastrointest. Tumors 2015, 2, 109-123.

79. Gerthofer, V.; Kreutz, M.; Renner, K.; Jachnik, B.; Dettmer, K.; Oefner, P.; Riemenschneider, M.J.; Proescholdt, M.; Vollmann-Zwerenz, A.; Hau, P.; et al. Combined Modulation of Tumor Metabolism by Metformin and Diclofenac in Glioma. Int. J. Mol. Sci. 2018, 19, 2586.

80. Tseng, H.W.; Li, S.C.; Tsai, K.W. Metformin Treatment Suppresses Melanoma Cell Growth and Motility through Modulation of Microrna Expression. Cancers 2019, 11, 209. [CrossRef]

81. Michishita, E.; Park, J.Y.; Burneskis, J.M.; Barrett, J.C.; Horikawa, I. Evolutionarily Conserved and Nonconserved Cellular Localizations and Functions of Human Sirt Proteins. Mol. Biol. Cell 2005, 16, 4623-4635. [CrossRef]

82. Matsushita, N.; Yonashiro, R.; Ogata, Y.; Sugiura, A.; Nagashima, S.; Fukuda, T.; Inatome, R.; Yanagi, S. Distinct Regulation of Mitochondrial Localization and Stability of Two Human Sirt5 Isoforms. Genes Cells 2011, 16, 190-202. [CrossRef]

83. Jung-Hynes, B.; Nihal, M.; Zhong, W.; Ahmad, N. Role of Sirtuin Histone Deacetylase Sirt1 in Prostate Cancer. A Target for Prostate Cancer Management Via Its Inhibition?" J. Biol. Chem. 2009, 284, 3823-3832. [CrossRef]

84. Barbagallo, I.; Parenti, R.; Zappala, A.; Vanella, L.; Tibullo, D.; Pepe, F.; Onni, T.; Volti, G.L. Combined Inhibition of Hsp90 and Heme Oxygenase-1 Induces Apoptosis and Endoplasmic Reticulum Stress in Melanoma. Acta Histochem. 2015, 117, 705-711. [CrossRef]

85. Gozzelino, R.; Jeney, V.; Soares, M.P. Mechanisms of Cell Protection by Heme Oxygenase-1. Annu. Rev. Pharmacol. Toxicol. 2010, 50, 323-354. [CrossRef]

86. Sacerdoti, D.; Singh, S.P.; Schragenheim, J.; Bellner, L.; Vanella, L.; Raffaele, M.; Meissner, A.; Grant, I.; Favero, G.; Rezzani, R.; et al. Development of Nash in Obese Mice Is Confounded by Adipose Tissue Increase in Inflammatory Nov and Oxidative Stress. Int. J. Hepatol. 2018, 2018, 3484107. [CrossRef]

87. Poljsak, B.; Milisav, I. Clinical Implications of Cellular Stress Responses. Bosn J. Basic Med. Sci. 2012, 12, 122-126. [CrossRef]

88. Choi, A.M.; Alam, J. Heme Oxygenase-1: Function, Regulation, and Implication of a Novel Stress-Inducible Protein in Oxidant-Induced Lung Injury. Am. J. Respir. Cell Mol. Biol. 1996, 15, 9-19. [CrossRef]

89. Bahmani, P.; Hassanshahi, G.; Halabian, R.; Roushandeh, A.M.; Jahanian-Najafabadi, A.; Roudkenar, M.H. The Expression of Heme Oxygenase-1 in Human-Derived Cancer Cell Lines. Iran. J. Med. Sci. 2011, 36, 260-265.

90. Chiang, S.K.; Chen, S.E.; Chang, L.C. A Dual Role of Heme Oxygenase-1 in Cancer Cells. Int. J. Mol. Sci. 2018, 20, 39. [CrossRef]

91. Ryter, S.W.; Choi, A.M. Targeting Heme Oxygenase-1 and Carbon Monoxide for Therapeutic Modulation of Inflammation. Transl. Res. 2016, 167, 7-34. [CrossRef]

92. Sena, P.; Mancini, S.; Benincasa, M.; Mariani, F.; Palumbo, C.; Roncucci, L. Metformin Induces Apoptosis and Alters Cellular Responses to Oxidative Stress in Ht29 Colon Cancer Cells: Preliminary Findings. Int. J. Mol. Sci. 2018, 19, 1478. [CrossRef]

93. Li, Y.; Wang, M.; Zhi, P.; You, J.; Gao, J.Q. Metformin Synergistically Suppress Tumor Growth with Doxorubicin and Reverse Drug Resistance by Inhibiting the Expression and Function of P-Glycoprotein in Mcf7/Adr Cells and Xenograft Models. Oncotarget 2018, 9, 2158-2174. [CrossRef]

94. Teh, J.T.; Zhu, W.L.; Newgard, C.B.; Casey, P.J.; Wang, M. Respiratory Capacity and Reserve Predict Cell Sensitivity to Mitochondria Inhibitors: Mechanism-Based Markers to Identify Metformin-Responsive Cancers. Mol. Cancer Ther. 2019, 18, 693-705. [CrossRef] [PubMed] 
95. Wheaton, W.W.; Weinberg, S.E.; Hamanaka, R.B.; Soberanes, S.; Sullivan, L.B.; Anso, E.; Glasauer, A.; Dufour, E.; Mutlu, G.M.; Budigner, G.S.; et al. Metformin Inhibits Mitochondrial Complex I of Cancer Cells to Reduce Tumorigenesis. Elife 2014, 3, e02242. [CrossRef]

96. Wang, H.; Cheng, Q.; Li, X.; Hu, F.; Han, L.; Zhang, H.; Li, L.; Ge, J.; Ying, X.; Guo, X.; et al. Loss of Tigar Induces Oxidative Stress and Meiotic Defects in Oocytes from Obese Mice. Mol. Cell Proteom. 2018, 17, 1354-1364. [CrossRef] [PubMed]

97. Du, Z.X.; Zhang, H.Y.; Meng, X.; Guan, Y.; Wang, H.Q. Role of Oxidative Stress and Intracellular Glutathione in the Sensitivity to Apoptosis Induced by Proteasome Inhibitor in Thyroid Cancer Cells. BMC Cancer 2009, 9, 56. [CrossRef]

98. Wong, E.Y.; Wong, S.C.; Chan, C.M.; Lam, E.K.; Ho, L.Y.; Lau, C.P.; Au, T.C.; Chan, A.K.; Tsang, C.M.; Tsao, S.W.; et al. Tp53-Induced Glycolysis and Apoptosis Regulator Promotes Proliferation and Invasiveness of Nasopharyngeal Carcinoma Cells. Oncol. Lett. 2015, 9, 569-574. [CrossRef]

99. Bensaad, K.; Tsuruta, A.; Selak, M.A.; Vidal, M.N.; Nakano, K.; Bartrons, R.; Gottlieb, E.; Vousden, K.H. Tigar, a P53-Inducible Regulator of Glycolysis and Apoptosis. Cell 2006, 126, 107-120. [CrossRef]

100. Winkler, B.S.; DeSantis, N.; Solomon, F. Multiple Nadph-Producing Pathways Control Glutathione (Gsh) Content in Retina. Exp. Eye Res. 1986, 43, 829-847. [CrossRef]

101. Zhou, J.H.; Zhang, T.T.; Song, D.D.; Xia, Y.F.; Qin, Z.H.; Sheng, R. Tigar Contributes to Ischemic Tolerance Induced by Cerebral Preconditioning through Scavenging of Reactive Oxygen Species and Inhibition of Apoptosis. Sci. Rep. 2016, 6, 27096. [CrossRef] [PubMed]

102. Heiss, K.; Raffaele, M.; Vanella, L.; Murabito, P.; Prezzavento, O.; Marrazzo, A.; Arico, G.; Castracani, C.C.; Barbagallo, I.; Zappala, A.; et al. (+)-Pentazocine Attenuates Sh-Sy5y Cell Death, Oxidative Stress and Microglial Migration Induced by Conditioned Medium from Activated Microglia. Neurosci. Lett. 2017, 642, 86-90. [CrossRef]

103. Salerno, L.; Amata, E.; Romeo, G.; Marrazzo, A.; Prezzavento, O.; Floresta, G.; Sorrenti, V.; Barbagallo, I.; Rescifina, A.; Pittala, V. Potholing of the Hydrophobic Heme Oxygenase-1 Western Region for the Search of Potent and Selective Imidazole-Based Inhibitors. Eur. J. Med. Chem. 2018, 148, 54-62. [CrossRef] [PubMed]

104. Lanteri, R.; Acquaviva, R.; di Giacomo, C.; Sorrenti, V.; Destri, G.L.; Santangelo, M.; Vanella, L.; di Cataldo, A. Rutin in Rat Liver Ischemia/Reperfusion Injury: Effect on Ddah/Nos Pathway. Microsurgery 2007, 27, $245-251$. [CrossRef] 